\title{
Emerging market MNEs as meta- integrators: the importance of internal networks
}

Article

Published Version

Narula, R. (2017) Emerging market MNEs as meta-integrators: the importance of internal networks. International Journal of Technology Management, 74 (1/2/3/4). pp. 214-220. ISSN 1741-5276 doi: https://doi.org/10.1504/IJTM.2017.083625 Available at https://centaur.reading.ac.uk/65843/

It is advisable to refer to the publisher's version if you intend to cite from the work. See Guidance on citing.

To link to this article DOI: http://dx.doi.org/10.1504/IJTM.2017.083625

Publisher: Inderscience

All outputs in CentAUR are protected by Intellectual Property Rights law, including copyright law. Copyright and IPR is retained by the creators or other copyright holders. Terms and conditions for use of this material are defined in the End User Agreement.

www.reading.ac.uk/centaur

\section{CentAUR}


Central Archive at the University of Reading

Reading's research outputs online 


\title{
Emerging market MNEs as meta-integrators: the importance of internal networks
}

\author{
Rajneesh Narula \\ Henley Business School, \\ University of Reading, \\ Whiteknights, Reading RG6 6UD, UK \\ Email: r.narula@henley.ac.uk
}

\begin{abstract}
The modern MNE has to be a 'meta-integrator', able to leverage knowledge within and between its different constituent affiliates, which requires efficient internal markets and well-structured cross-border hierarchies. The current generation of EMNEs need to strengthen their ownership advantages to achieve such internal embeddedness, which are hard to acquire, and must be learnt. I frame this discussion in the ongoing debate about the nature of ownership advantages. The ability to be competitive in an era of globalisation depends as much on the EMNE's technological assets as it does on its ability to achieve economies of common governance. The EMNE has to be able to promote internal knowledge flows, both to and from the parent, as well as between affiliates located in different countries. This is essential to achieve organisational, scale and scope economies.
\end{abstract}

Keywords: ownership advantages; emerging country MNEs; EMNEs; organisational skills; technological assets; knowledge flows; embeddedness; internationalisation.

Reference to this paper should be made as follows: Narula, R. (2017) 'Emerging market MNEs as meta-integrators: the importance of internal networks', Int. J. Technology Management, Vol. 74, Nos. 1/2/3/4, pp.214-220.

Biographical notes: Rajneesh Narula is the John H. Dunning Chair of International Business at the University of Reading. He has held previous appointments at Copenhagen Business School, University of Maastricht and BI Norwegian School of Business.

\section{Introduction}

The last decade has seen the discussion about emerging country MNEs (EMNEs) move towards to maturity. The argument still ongoing is to what degree EMNEs have some innate advantage over other MNEs that allows them to do things differently, and whether these differences will persist. It has been my contention that an MNE's experience in internationalisation is more significant than its national origin, and that the core issue for an MNE to succeed in the longer run is its ability to acquire and leverage ownership advantages or firm-specific assets (FSAs) (I use both terms interchangeably throughout this paper) in a variety of locations simultaneously, and that this imperative trumps all others (Narula, 2012, 2015; Cuervo-Cazurra, 2012; Madhok and Keyhani, 2012). 
Much of the debate on EMNEs has focused on their weakness in technological assets, and the extent to which they possess other kinds of advantages that overcome this deficiency. These 'other' assets are often associated with the experience of working in institutional voids, the relevance of home country experience to foreign markets, and the ability to acquire and internalise technological assets from other firms rapidly. I do not dispute that there is some value to such assets, but feel these advantages are insufficient for the EMNE to succeed in the longer run. I return to basic international business (IB) theory to draw our attention to aspects of FSAs that have unaccountably been neglected in the discussion. Key among these is that a firm is 'multinational' only when there is a degree of active coordination and control of the foreign operations by the parent firm. The ability to establish international operations (whether through M\&A or greenfield investments) does not automatically imply that a firm will efficiently manage these foreign affiliates. Indeed, some EMNEs have preferred to manage their foreign operations as a loose constellation of activities under common ownership (Wang et al., 2013), given their weakness in the organisational skills needed to achieve economies of common governance. The modern MNE has to be a 'meta-integrator', able to leverage knowledge within and between the different constituent affiliates of its international network, which requires efficient internal markets and well-structured cross-border hierarchies.

I argue that these types of FSAs derive to a great degree from experience, and the newer EMNEs are deficient in these assets. EMNEs that are new at managing international activities) tend to lack internal organisational capabilities and are less able to actively manage (and rationalise) their foreign subsidiaries. The long-term success of the current generation of EMNEs - like earlier 'waves' of EMNEs (Gammeltoft et al., 2010) - depends crucially on their ability to promote internal knowledge flows, both to and from the parent, as well as between affiliates located in different countries, and the ability to achieve organisational, scale and scope economies. This is made no easier by institutional, organisational and technological distance. EMNEs will need to strengthen their FSAs necessary to achieve such internal embeddedness.

\section{Ownership advantages and managing cross-border hierarchies}

The concept of ownership advantages lies at the core of IB theory. Although there are some minor variations in the taxonomy of FSAs used by different authors [see e.g., Cantwell et al. (2010) versus Narula $(2012,2015)$ versus Rugman and Verbeke (2001), Grøgaard and Verbeke (2012) and Verbeke (2009)] $]^{1}$, at the heart of the ownership advantage concept are two core subsets of assets (the nature of the third subset is in dispute), both of which are necessary for an MNE. The first is technology-type FSAs (Oa), which are typically associated with outputs from $R \& D$, such as a patent, a process technology, or a brand, or embodied in personnel.

Of equal importance is the second class of FSAs that relates to the firm's ability to minimise transaction costs and organise its activities, known as transaction-type FSAs, or Ot). Apart from being able to exploit external market imperfections, the aspiring MNE needs to be able to manage its multiple operations (and internal markets) effectively. An MNE must be able to achieve economies of common governance (Dunning, 1993, 2001). That is, it must have the ability to exploit its ownership advantages across locations, such that there are returns to managing multiple activities in several locations. For instance, an 
MNE may streamline certain activities (such as HR, or production) between countries to achieve lower costs. Indeed, the ability to exploit economies in the use of its knowledge or physical assets in several markets is a raison d'etre for the modern MNE. Figure 1 summarises the attributes of Oa and Ot FSAs, as well as a third, less universally accepted category (Figure 1).

Figure 1 A classification of FSAs associated with MNEs

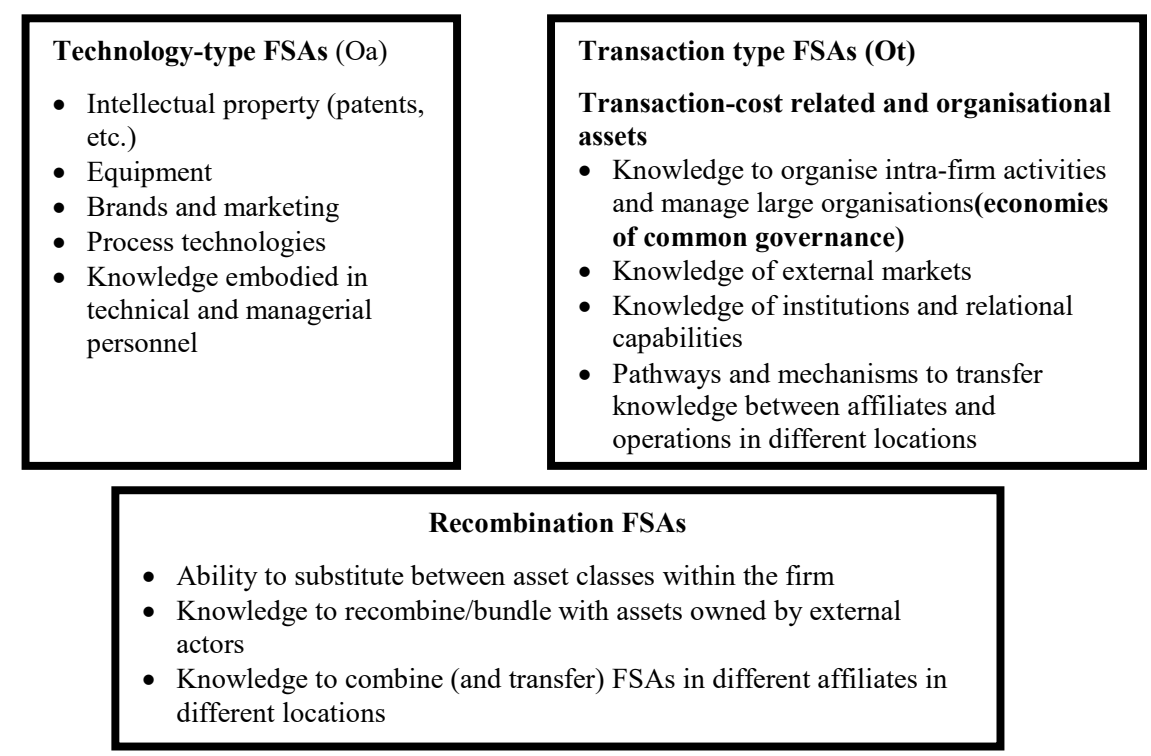

It is my opinion that the parents of many to the current generation of EMNEs may well have acquired some degree of expertise in managing networks of subsidiaries in the home country, but these FSAs are not always available to use abroad, for the very good reason that such assets may be location-bound, because they are specific to a particular location, often only at home, or in similar host countries, (Rugman and Verbeke, 1992; Carney et al., 2016). Firms may internationalise in ignorance of whether these assets are transferable: it is not straightforward to determine which assets are location-bound, and which FSAs can be utilised abroad, and which sets of institutional knowledge are relevant in particular host countries. Indeed, in many instances it is only through failure that firms realise the limits applying their existing management and organisational expertise to new operations in new locations. It must be able to transfer this knowledge from parent units to subsidiaries. That is, to prosper, the MNE must be able to diffuse its FSAs to its subsidiaries, maximise the returns on it collective FSAs, and to lower costs on an MNE-wide basis (Schleimer and Pedersen, 2013).

\section{The modern MNE as a meta-integrator}

I have described the MNE elsewhere as a 'meta-integrator' (Narula 2014). It must manage knowledge resident within the MNE, and extract an advantage from it (Madhok, 2015). The modern MNE requires the capability to recombine diverse knowledge sets, 
and this includes assets that are part of different affiliates within the same MNE or firm, or to combine assets that are located inside the firm with those outside the firm, whether these are part of the L advantages of its location, or part of the FSAs of an independent firm.

As such, a crucial aspect of a MNE's ability to generate rents from cross-border hierarchies is the ability to move information from location to another to maximise its usage and value. However, transferring knowledge between two establishments located in different countries is fraught with difficulties. Although it is assumed that the MNE is an especially efficient mechanism to transfer assets to and from its various geographically dispersed subsidiaries (Kogut and Zander, 1993), this is not always so. MNE internal markets in general are considered to be more efficient than markets in transferring knowledge, but this does not mean that they are always more efficient. The ability to organise intra-firm transactions is an FSA that is essential for a firm to become a sustainable MNE, but such expertise is not easily acquired, and this largely relies on learning-by-doing. Younger MNEs tend not to have the knowledge to systematically 'translate' and transfer managerial practices and rent-generating FSAs abroad on a systematic basis (Narula, 2014). Without this FSA the MNE is simply a multi-locational collection of free-standing establishments held together by common ownership.

\section{The capacity to recombine assets}

A number of recent conceptual contributions have highlighted that moving and utilising asset between various internal units of the MNE and external actors require what are known as recombination advantages (Figure 1). These allow the firm to 'recombine' assets to create a new 'bundle' by substituting other internal (or external) assets for those the firm does not possess (Verbeke, 2009; Hennart, 2009). Firms can overcome a weakness in one set of assets (say, for an airline, new energy efficient aircraft) by strength in another type of FSA (e.g., a superior aircraft logistical system to maximise aircraft use). For an EMNE, the ability to organise intra-firm transactions more efficiently, or to acquire resources from external markets at lower prices may help overcome the weakness in technology-type FSAs. Conversely, a strong portfolio of proprietary technologies may compensate for poor knowledge of markets or inefficient management. An EMNE can overcome the absence of unique technologies by being able to organise its intra-firm transaction so efficiently that overall it still generates a cost advantage (Collinson and Narula, 2014). This is akin to entrepreneurial capacity, and reflects an 'agility' that MNEs can have which allows them through 'entrepreneurial endeavour to overcome the advantage deficit' they may suffer (Madhok, 2015). It involves having an intricate knowledge of the assets available (and those unavailable) in each of its operations, an understanding of their location-boundedness, their value (vis-à-vis external alternatives), and the mechanisms to transfer them effectively from one location to another.

Being able to move knowledge efficiently between establishments is crucial for the EMNE, just as it is for other MNEs. This internal knowledge transfer is facilitated by the affiliate's 'internal embeddedness' (Meyer et al., 2011; Narula, 2014). Internal embeddedness crucially requires both parties to be willing to transfer, so one must be willing to 'give' and the other to 'receive' (Gupta and Govindarajan, 2000). Transferring knowledge also depends upon both parties having similar levels of absorptive capacity. 
EMNEs have shown a propensity to expand internationally through acquisitions. Knowledge acquisition by this means has its disadvantages. A recently-acquired establishment in a given location may be an 'outsider' to the MNE (Monteiro et al., 2008) and such acquired subsidiaries often have no internal embeddedness. Employees of acquired subsidiaries are viewed with some suspicion by existing staff, and vice versa. There is considerable organisational inertia, especially in the area of $R \& D$, and key individuals may show a reluctance to engage in $R \& D$ cooperation with former rivals (Criscuolo and Narula, 2007). Blomkvist et al. (2014) find that there are still tangible differences between acquired and greenfield subsidiaries even after 100 years. As Mudambi et al. (2014) note, a common culture is important in transferring tacit knowledge. Knowledge is context-specific (and location-specific) so that there is need for common contexts of experience between sender and recipient to convert the transferred (and often tacit) knowledge to explicit knowledge (Nonaka et al., 2000). Just because there is common ownership does not mean that the two establishments have the same context of experience, unless the subsidiary is populated mainly by expatriates from the home country. Indeed, this is why a number of nascent MNEs have relied upon a large contingent of expatriates in the senior management and technical personnel of the home country (Perez and Pla-Barber, 2005; Tan and Mahoney, 2006; Beamish and Inkpen, 1998). Such transplant subsidiaries are ultimately not sustainable, because the costs of a transplant strategy outweigh the benefits in the long run.

This brings me to the issue of 'bandwidth'. Internal embeddedness is not simply a matter of 'pathways' between parent and subsidiary, it is also about their 'bandwidth', or the width of these pathways. High bandwidth connections imply regular, efficient and intensive two-way knowledge flows, for instance through systematic face-to-face engagement between scientists, engineers and managers in different units. High bandwidth links are resource-intensive and take time to establish (Narula, 2014). Where the FSA to be shared is associated with tacit knowledge, greater bandwidth is required, especially when the knowledge is embodied in technical personnel.

\section{Closing remarks}

I have tried to highlight that managing an MNE is no simple process, and a viable MNE is requires mechanisms for efficient coordination, control, in addition to internal pathways for knowledge flows between its various geographically dispersed activities. Knowledge transfer depends on creating the appropriate routines, and these need to be codified in some way for them to be transferred. The literature on EMNEs has neglected that distances matter within an MNE as well. Creating efficient internal pathways and networks is no easy task, and achieving economies of common governance matters even more in a world of intense international competition. Unfortunately, there has been relatively little research into understanding how EMNEs can do so effectively, possibly because these types of FSAs are difficult to quantify and objectively evaluate ex ante as to whether they are location-bound or not. This is a rich and unexplored area for research. How do MNEs learn to organise themselves efficiently? What mechanisms can be employed to internalise this knowledge from acquired operations? How do firms avoid organisational inertia? What are the limits to using expatriation as a means to transfer organisational practices and routines? 
Many previous generations of EMNEs have stumbled at this very hurdle. Initial rapid expansion by Japanese MNEs in the 1980s faced the hurdle that Japanese organisational practices (which were the primary ownership advantage of Japanese firms) were not easily transferable to other countries. Many of the current generation of EMNEs that have sought to rapidly expand internationally will likely also stumble if they cannot create coherence and structure that permits them to derive economies of scale, scope and common governance across their geographically dispersed constellation of affiliates.

\section{Acknowledgements}

I wish to thank Maite Bezerra, Kristin Brandl, and Jongmin Lee for their comments and assistance. All errors remain my own.

\section{References}

Beamish, P.W. and Inkpen, A.C. (1998) 'Japanese firms and the decline of the Japanese expatriate', Journal of World Business, Vol. 33, No. 1, pp.35-50.

Blomkvist, K., Kappen, P. and Zander, I. (2014) 'Win, place, or show? How foreign investment strategies contribute to the technological growth of the multinational corporation', Long Range Planning, Vol. 47, No. 1, pp.16-31.

Cantwell, J., Dunning, J.H. and Lundan, S.M. (2010) 'An evolutionary approach to understanding international business activity: the co-evolution of MNEs and the institutional environment', Journal of International Business Studies, Vol. 41, No. 4, pp.567-586.

Carney, M., Dieleman, M. and Taussig, M. (2016) 'How are institutional capabilities transferred across borders?', Journal of World Business, in press.

Collinson, S. and Narula, R. (2014) 'Asset recombination in international partnerships as a source of improved innovation capabilities in China', Multinational Business Review, Vol. 22, No. 4, pp.394-417.

Criscuolo, P. and Narula, R. (2007) 'Using multi-hub structures for international R\&D: organisational inertia and the challenges of implementation', Management International Review, Vol. 47, No. 5, pp.639-660.

Cuervo-Cazurra, A. (2012) 'Extending theory by analyzing developing country multinational companies: solving the goldilocks debate', Global Strategy Journal, Vol. 2, No. 3, pp.168-187.

Dunning, J.H. (1993) Multinational Enterprises and the Global Economy, Addison Wesley, Wokingham, Berkshire, UK.

Dunning, J.H. (2001) 'The eclectic (OLI) paradigm of international production: past, present and future', International Journal of the Economics of Business, Vol. 8, No. 2, pp.173-190.

Gammeltoft, P., Barnard, H. and Madhok, A. (2010) 'Emerging multinationals, emerging theory: macro-and micro-level perspectives', Journal of International Management, Vol. 16, No. 2, pp.95-101.

Grøgaard, B. and Verbeke, A. (2012) 'Twenty key hypotheses that make internalization theory the general theory of international strategic management', in Verbeke, A. and Merchant, $\mathrm{H}$. (Eds.): Handbook of Research in International Strategic Management, pp.7-30.

Gupta, A.K. and Govindarajan, V. (2000) 'Knowledge flows within multinational corporations', Strategic Management Journal, Vol. 21, No. 4, pp.473-496.

Hennart, J.F. (2009) 'Down with MNE-centric theories! Market entry and expansion as the bundling of MNE and local assets', Journal of International Business Studies, Vol. 40, No. 9, pp.1432-1454. 
Kogut, B. and Zander, U. (1993) 'Knowledge of the firm and the evolutionary-theory of the multinational corporation', Journal of International Business Studies, Vol. 24, No. 4, pp.625-645.

Madhok, A. (2015) 'Commentary: a critical assessment of firm advantage and implications for multinationals and multinationalizing firms', Journal of World Business, Vol. 50, No. 4, pp.627-630.

Madhok, A. and Keyhani, M. (2012) 'Acquisitions as entrepreneurship: asymmetries, opportunities, and the internationalization of multinationals from emerging economies', Global Strategy Journal, Vol. 2, No. 1, pp.26-40.

Meyer, K.E., Mudambi, R. and Narula, R. (2011) 'Multinational enterprises and local contexts: the opportunities and challenges of multiple embeddedness', Journal of Management Studies, Vol. 48, No. 2, pp.235-252.

Monteiro, L.F., Arvidsson, N. and Birkinshaw, J. (2008) 'Knowledge flows within multinational corporations: explaining subsidiary isolation and its performance implications', Organization Science, Vol. 19, No. 4, pp.90-107.

Mudambi, R., Piscitello, L. and Rabbiosi, L. (2014) 'Reverse knowledge transfer in MNEs: subsidiary innovativeness and entry modes', Long Range Planning, Vol. 47, No. 1, pp.49-63.

Narula, R. (2010) 'Keeping the eclectic paradigm simple', Multinational Business Review, Vol. 18, No. 2, pp.35-50.

Narula, R. (2012) 'Do we need different frameworks to explain infant MNEs from developing countries?', Global Strategy Journal, Vol. 2, No. 1, pp.41-47.

Narula, R. (2014) 'Exploring the paradox of competence-creating subsidiaries: balancing bandwidth and dispersion in MNEs', Long Range Planning, Vol. 47, Nos. 1-2, pp.4-15.

Narula, R. (2015) 'The viability of sustained growth by India's MNEs: India's dual economy and constraints from location assets', Management International Review, Vol. 55, No. 2, pp.191-205.

Nonaka, I., Toyama, R. and Konno, N. (2000) 'SECI, Ba and leadership: a unified model of dynamic knowledge creation', Long Range Planning, Vol. 33, No. 1, pp.5-34.

Perez, J.B. and Pla-Barber, J. (2005) 'When are international managers a cost effective solution? The rationale of transaction cost economics applied to staffing decisions in MNCs', Journal of Business Research, Vol. 58, No. 10, pp.1320-1329.

Rugman, A.M. and Verbeke, A. (1992) 'A note on the transnational solution and the transaction cost theory of multinational strategic management', Journal of International Business Studies, Vol. 23, No. 4, pp.761-771.

Rugman, A.M. and Verbeke, A. (2001) 'Subsidiary-specific advantages in multinational enterprises', Strategic Management Journal, Vol. 22, No. 3, pp.237-250.

Schleimer, S.C. and Pedersen, T. (2013) 'The driving forces of subsidiary absorptive capacity', Journal of Management Studies, Vol. 50, No. 4, pp.646-672.

Tan, D. and Mahoney, J.T. (2006) 'Why a multinational firm chooses expatriates: integrating resource-based, agency and transaction costs perspectives', Journal of Management Studies, Vol. 43, pp.457-484.

Verbeke, A. (2009) International Business Strategy, Cambridge University Press, Cambridge.

Wang, S.L., Luo, Y., Lu, X., Sun, J. and Maksimov, V. (2013) 'Autonomy delegation to foreign subsidiaries: an enabling mechanism for emerging-market multinationals', Journal of International Business Studies, Vol. 45, No. 2, pp.111-130.

\section{Notes}

1 For instance, the Cantwell et al. (2010) view is that knowledge of institutions can be categorised as a separate FSA type (Oi), while Narula $(2010,2012)$ argues that these are part of transaction-type $\mathrm{O}$ assets $(\mathrm{Ot})$. 